\title{
Perencanaan Constructed Wetland Sebagai Media Reduksi Greywater Dan Pengendali Banjir: Studi Kasus Perumahan Sutorejo Indah
}

\author{
1. Muhammad Rijal Fauzi, Mas Agus Mardyanto. \\ Jurusan Teknik Lingkunan, Fakultas Teknik Sipil dan Perencanaan, Institut Teknologi Sepuluh \\ Nopember (ITS) \\ J1. Arief Rahman Hakim, Surabaya 60111 Indonesia \\ e-mail:Rijal.f12@mhs.enviro.its.ac.id
}

\begin{abstract}
Abstrak-Minimnya jangkauan pengolahan air buangan rumah tangga (greywater) dan sistem drainase yang kurang dipelihara dengan baik di Perumahan Sutorejo Surabaya menyebabkan permasalahan banjir dan pengolahan air limbah tidak terselesaikan dengan baik. Adanya instalasi pengolahan constructed wetland membantu mereduksi kandungan air limbah rumah tangga (Greywater) dan bozem sebagai pengendali banjir pada saat musim penghujan di perumahan Sutorejo Indah juga nantinya akan menjadi tambahan nilai estetika. Dalam perencanaan Constructed Wetland (CW) dan bangunan pengendali banjir ini direncanakan mulai dari perencanaan survei lokasi, studi literatur, perencanaan detailed engineering design, standard operating managementnya, hingga BOQ serta RAB untuk perencanaan constructed wetland dan bangunan pengendali banjir. Perencanaan Constructed Wetland di perumahan Sutorejo Indah ini digunakan untuk mengolah limbah greywater dengan tingkat efisiensi BOD, COD, dan TSS masingmasing 86,93\%, 94,28\% dan 87\%. Adapun untuk bangunan pengendali banjir dapat menampung debit banjir sebesar 0,058 $\mathbf{m}^{3}$,/detik
\end{abstract}

\section{Kata kunci-Constructed Wetland, Drainase, Greywater}

\section{PENDAHULUAN}

$\mathrm{S}$ EKTOR perumahan merupakan salah satu sektor yang sangat cepat pertumbuhannya Di Indonesia, dengan permintaan yang semakin besar dari tahun ke tahun, sektor perumahan merupakan sektor yang cukup menjanjikan dalam investasi. Besarnya permintaan perumahan dari pasar membuat pihak developer terlalu memfokuskan pada cepatnya pembangunan supaya wilayah dapat siap huni dengan cepat, namun perhatian terhadap pengolahan limbah rumah tangga juga drainase sedikit dikesampingkan sehingga terdapat beberapa permasalahan terkait 2 aspek tersebut. Adanya perkembangan penduduk yang begitu cepat dan masih terbatasnya sarana sanitasi juga instalasi pengolahan air limbah menyebabkan tingginya pencemarana air permukaan, terutama air sungai. Instalasi pengolah air limbah menyebabkan tingginya pencemaran air permukaan, terutama air sungai. Instalasi pengolah air limbah menyebabkan tingginya pencemaran air permukaan, terutama air sungai. Instalasi pengolah air limbah rumah tangga dipandang mahal dan sulit diterapkan di negara berkembang.
Perumahan Sutorejo merupakan perumahan semi elite yang terletak di daerah Mulyosari, Kota Surabaya. Dikarenakan perumahan semi elite, perumahan ini bercampur antara perumahan kalangan menengah ke atas dan kalangan menengah ke bawah. Dan belum memadainya on site dan off site Di Perumahan Sutorejo inilah diperlukan perencanaan constructed wetland yang mempu dengan biaya lebih terjangkau dan memiliki fungsi yang lebih cocok untuk perumahan.

Constructed wetland $(\mathrm{CW})$ menawarkan Teknologi mudah dan terjangkau dalam perencanaan maupun pengoperasian sistem pengolahan air limbah rumah tangga. Dalam paper ini akan dibahas mengenai tipe $\mathrm{CW}$, jenis Tanaman yang akan digunakan dalam perencanaan $\mathrm{CW}$, media perencanaan, Bentuk CW, kinerja $\mathrm{CW}$, juga $\mathrm{BOQ}$ dan $\mathrm{RAB} \mathrm{CW}$. $\mathrm{CW}$ tipe horizontal subsurface fclow (SSF) cocok untuk daerah perkotaan yang tidak terjangkau fasilitas pengolahan air limbah yang terpusat, sehingga dapat dibangun secara individual. CW tipe SSF lebih fleksibel dalam penempatannya, dan tidak memerlukan lahan yang luas. Pemilihan jenis tanaman dalam CW-SSF disesuaikan dengan lokasi tempat $\mathrm{CW}$ dibangun, teduh atau terpapar panas. Kinerja $\mathrm{CW}$ lebih baik menggunakan kombinasi berbagai jenis tanaman, dibandingkan dengan menggunakan tanaman tunggal.

CW merupakan pengolahan yang memasukkan faktor utama, yaitu area yang tergenangi air dan mendukung kehidupan tumbuhan air sejenis hydrophyta. Media tempat tumbuh berupa tanah yang selalu digenangi air (basah). Sedang menurut Metcalf \& Eddy (1993) CW merupakan sistem yang termasuk pengolahan alami, dimana terjadi aktivitas pengolahan sedimentasi, filtrasi, transfer gas, adsorbsi, pengolahan kimiawi, dan biologis, karena aktivitas mikroorganisme dalam tanah dan aktivitas tanaman [1].

CW dirancang dengan perlakuan lebih terkontrol, misalnya dengan pengaturan hydraulic retention time (HRT) dan hydraulic loading rate (HLR) untuk mempertimbangkan dimensinya. Dari aspek hidraulika dapat diklasifikasikan menjadi CWs dengan permukaan air bebas (free water surface/FWS) dan CW aliran di bawah permukaan (subsurface Flow/SSF). Berdasarkan pola aliran, CW dapat diklasifikasikan menurut arah aliran horisontal dan vertikal [2].

Pada perencanaan $\mathrm{CW}$, perlu adanya media yang digunakan untuk menurunkan beban pencemar. Salah satunya adalah 
adanya media tumbuh tanaman yang nantinya akan berfungsi sebagai penurun beban pencemar utama dalam perencanaan

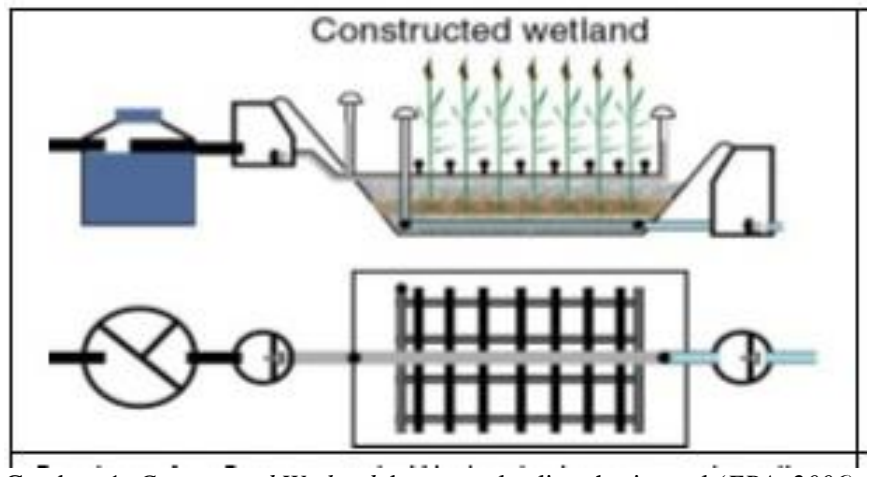

Gämbar. 1. Constructed Wetland dengan pola aliran horizontal (EPA. 2006).

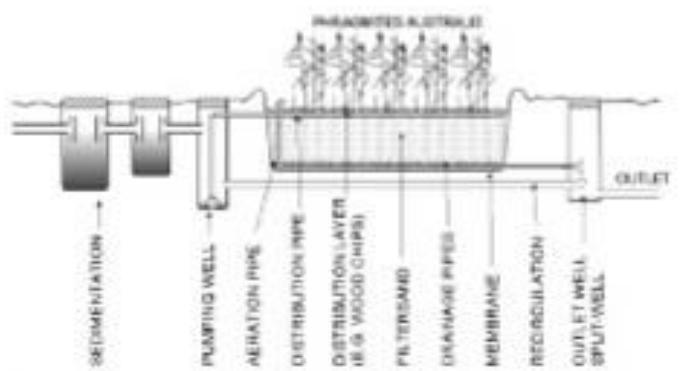

Gambar. 1. Constructed Wetland dengan pola aliran horizontal (EPA, 2006).

$\mathrm{CW}$ ini. Jenis tanaman yang sering digunakan untuk CW merupakan tanaman yang dapat bertahan dalam kondisi tergenang (submerged plant atau amphibious plant). Pada umumnya terdapat 3 kelompok yang didasari oleh area pertumbuhannya di dalam air. Ketiga kelompok tanaman tersebut adalah:

A. Tanaman yang mencuat ke permukaan air

Merupakan tanaman air yang memiliki sistem perakaran pada tanah di dasar perairan dan berada jauh di atas air

B. Tanaman yang mengambang dalam air

Merupakan tanaman air yang seluruh akar tanaman (akar, batang, daun) berada di dalam air

C. Tanaman yang mengapung di dalam air

Dalam perencanaan $\mathrm{CW}$ ini, direkomendasikan menggunakan tanaman yang selain memiliki fungsi untuk menurunkan kadar beban pencemar dengan efisien yang tinggi dan baik, juga memiliki fungsi lain sebagai nilai estetika diharapkan CW ini menjadi taman juga sebagai unit reduksi beban pencemar greywater.

Untuk jenis tanaman yang akan digunakan sebagai media penurun beban pencemar, digunakan 2 jenis tanaman, yaitu Bintang Air (Cyperus alternifolius) dan cattail (Thypa Angustifiola).

Bintang air, atau yang memiliki bahasa latin Cyperus alternifolius merupakan tanaman yang memiliki nilai estetika yang baik namun memiliki kemampuan untuk mereduksi beban pencemar limbah. Tanaman ini mempunyai tangkai tangkai berbentuk segitiga, dengan panjang batang dewasa antara 0,51,5 meter. Tangkai menyangga daun berbentuk sempit dan datar, mengelilingi ujung tangkai secara simetris membentuk pola melingkar mirip cakram. Panjang daun berkisar antara $12-15 \mathrm{~cm}$ dan pada bagian tengah-tengah daun tumbuh bunga-bunga kecil bertangkai, berwarna kehijauan. berikut data singkat mengenai Cypernus alternifolius[3].

menyebutkan bahwa tanaman tersebut merupakan tanaman hiasyang berasal dari Madagaskar dan merupakan jenis lain dari tanaman papyrus yang berasal dari Sungai Nil. Dapat tumbuh cepat di lingkungan basah (berair) dengan variasi ketinggian tanaman antara 0,5-1,5 meter. Berkembang biak setiap bulan secara vegetatif melalui sistem perakaran maupun secara generatif melalui biji yang terletak di ujung batang pada pangkal daun. [4].

\section{Metode PerencanaAn}

Perencanaan dilakukan di Perumahan Sutorejo Indah, tepatnya di daerah Sutorejo Tengah V dengan luas lahan yang akan direncanakan sebesar 60,7 m x $38 \mathrm{~m}$. Dengan sebelah barat dari lokasi terdapat lahan persawahan dimana drainase akan diarahkan menuju sana. Kerangka pelaksanaan perencanaan merupakan dasar dan alur pemikiran yang digunakan untuk melaksanakan tahapan perencanaan. Kerangka perencanaan dibuat dalam bentuk gambaran visual tahapan perencanaan sebagai acuan untuk mempermudah perencana dalam melaksanakan perencanaan dan mengurangi risiko yang dapat terjadi selama berlangsungnya perencanaan.

\section{HASIL DAN PENJELASAN}

Setelah mengecek hasil kondisi eksisting yang ada, ternyata tidak semua perumahan dapat dilayani oleh $\mathrm{CW}$ tersebut. Hal ini dikarenakan beberapa perumahan mempunyai aliran yang tidak menuju ke daerah yang akan direncanakan. Menurut penyusun, hal ini disebabkan elevasi dari tanah pada wilayah tersebut berbeda dengan wilayah yang aliran greywaternya akan mengalir ke daerah perencanaan, ada pula arah alirannya sudah ditentukan menuju tempat lain.

Mengacu pada kondisi seperti ini, ditentukan debit yang akan masuk inlet sebesar $34,29 \mathrm{~m}^{3} /$ hari, melayani $200 \mathrm{KK}$ pada perumahan Sutorejo Indah. Asumsi ini mengacu pada pergub Jatim no. 72 th.2013 (120 1/orang.hari).

\section{Perhitungan Dimensi Constructed Wetland}

Setelah mengetahui debit yang akan masuk ke perencanaan CW. Ditentukan berapa debit pundak (Qpeak). Tujuan mengetahui debit puncak adalah sebagai acuan dasar dalam perencanaan dimensi $\mathrm{CW}$. Adapun rumus untuk menentukan debit puncak sebagai berikut.

Qpeak $=Q \times$ faktor puncak

Dimana nilai faktor puncak yang digunakan adalah 1,6 yang didapat dengan rumus sebagai berikut.

$$
f p=\frac{18+p^{0,5}}{(4+p)^{0.5}}
$$

Dimana $\mathrm{p}$ merupakan jumlah penduduk yang akan dilayani, berikut hasil perhitungannya.

$$
f p=\frac{18+1000^{0,5}}{(4+1000)^{0,5}}=1,56 \sim 1,6
$$

Setelah ditentukan faktor puncaknya, ditentukan Qpeak yang nantinya akan digunakan sebagai acuan untuk Qinlet dalam 
perencanaan CW. Adapun rumus untuk mendapatkan $\mathrm{Q}_{\text {peak }}$ adalah sebagai berikut.

$$
\mathrm{Q}_{\text {peak }}=Q \times f p
$$

Dengan diketahui $\mathrm{Q}$ greywater dalam perencanaan adalah 84 $\mathrm{m} 3 /$ hari, maka besar Qpeak adalah

Qpeak $=84 \times 1,6$

Sehingga hasil yang didapat adalah 134,4 m3/hari. Setelah diketahui Qpeak yang akan dijadikan sebagai Qinlet, dapat diketahui rumus untuk mengetahui luas $\mathrm{CW}$. Sebelum menuju ke luas CW, perlu diketahui td', dimana td' merupakan waktu detensi air limbah untuk berada di media $\mathrm{CW}$. Adapun rumus untuk mengetahui td' ialah sebagai berikut.

$\mathrm{td}^{\prime}=(-(\ln B O D$ outlet /inlet $)) / k t$

td': waktu detensi media $\mathrm{CW}$

KT: konstanta ketergantungan pada temperatur

untuk mengetahui nilai KT, dilakukan rumus sebagai berikut.

$\mathrm{KT}=\mathrm{K} 20(1.1)(\mathrm{T}-20), \mathrm{T}$ dalam celcius

Dengan K20 senilai 0,27779 T yang diketahui dari eksisting adalah 21,5O, maka nilai KT adalah

$$
\begin{aligned}
& \mathrm{KT}=\mathrm{K} 20\left(1.1^{(\mathrm{T}-20)}\right), \mathrm{T} \text { dalam celcius } \\
& \mathrm{KT}=0,2779\left(1.1^{(18-20)}\right) \\
& \mathrm{KT}=0,3206
\end{aligned}
$$

Setelah mendapatkan nila KT, maka dapat dihitung berapa td' dalam perencanaan $\mathrm{CW}$.

\section{$\mathrm{td}^{\prime}=(-(\ln B O D$ outlet /inlet $)) / k t$}

dengan BODinlet yang didapat dari data primer sebesar 40 $\mathrm{mg} / \mathrm{l}$ dan BODoutlet yang diinginkan nanti adalah $25 \mathrm{mg} / \mathrm{l}$, maka nilai td adalah

$$
\begin{aligned}
\mathrm{td}^{\prime}=\left(-\left(\ln \frac{40 \mathrm{mg}}{\mathbb{d}} / 28 \mathrm{mg} / \mathrm{l}\right)\right) / 0,229 \\
\mathrm{td}^{\prime}=1,5 \text { hari } \sim 2 \text { hari }
\end{aligned}
$$

Setelah mendapatkan nilai td', maka dapat diketahui volume CWyang dibutuhkan. Yaitu dengan rumus sebagai berikut.

$$
V=\text { Qinlet } \times t d^{l}
$$

$$
=\frac{134,4 \mathrm{~m} 3}{\text { hari }} \times 2 \text { hari }=208,7 \mathrm{~m}^{\mathrm{a}}
$$

Setelah diketahui volume yang dibutuhkan, tidak bisa langsung diketahui dimensi CWdengan rumus panjang $\mathrm{x}$ lebar $\mathrm{x}$ tinggi, hal ini dikarenakan ada rumus tertentu untuk menentukan luas area dari $\mathrm{CW}$. adapun rumus untuk menentukan luas areanya adalah sebagai berikut.

$$
A c=\frac{Q}{K s . s}
$$

Across: Luas Area (m2)

Q: Debit (m3/s)

Ks: konduktivitas hidrolis (m3/m2.hari)

Setelah ketemu Across, dapat diketahui Lebar dari CW, adapun rumus yang digunakan adalah sebagai berikut.

Lebar Basin $=($ Across /kedalaman Basin $)$

Dimana kedalaman basin adalah $1 \mathrm{~m}$, maka lebar untuk CWadalah

$$
\text { Lebar Basin }=\frac{17,91 \mathrm{~m}^{2}}{1 \mathrm{~m}}
$$

$$
=17,91 \mathrm{~m}
$$

Setelah diketahui lebar basin, langkah berikutnya adalah mengetahui panjang dari basin $(\mathrm{CW})$ itu sendiri. Adapun rumus yang digunakan adalah sebagai berikut.

Panjang Basin $(L)=\left(t^{t} * Q\right) /(W *$ kedalaman Basin $* \alpha$

$$
\begin{aligned}
& =\frac{2 \text { hari } \times 134,4 \mathrm{~m}^{\mathrm{a}} / \mathrm{h}}{17,91 \mathrm{~m} \times 1 \mathrm{~m} \times 0,35} \\
& =31,4 \mathrm{~m}
\end{aligned}
$$

Setelah mendapatkan panjang dan lebar basin, maka dapat ditentukan untuk luas perrmukaan dari $\mathrm{CW}$, adapun untuk rumusnya adalah sebagai berikut.

$$
\begin{aligned}
& \text { As }=\text { panjang basin } \times \text { lebar basin } \\
& =17,91 \mathrm{~m} \times 33,3 \mathrm{~m} \\
& =562,9 \mathrm{~m} 2
\end{aligned}
$$

\section{Perhitungan Efisiensi Removal}

Setelah mendapatkan luas permukaan dari costructed wetland, maka dapat ditentukan nilai dari hydraulic loading rate, adapun rumus yang digunakan sebagai berikut.

$$
\begin{aligned}
& \text { hydraulic loading rate }=\frac{Q}{A s} \\
& =\frac{134,4 \mathrm{~m}^{\mathrm{a}} / \mathrm{h}}{596,3 \mathrm{~m}^{2}} \\
& =0,225 \frac{\mathrm{m}^{\mathrm{a}}}{\mathrm{m}^{2} \text {. hari }}
\end{aligned}
$$

Setelah mendapatkan nilai dari hydraulic loading rate, maka langkah berikutnya adalah menentukan BOD5 loading rate. Adapun rumus yang digunakan sebagai berikut.

$$
\begin{aligned}
& \text { BOD } D_{5} \text { Loading Rate }=Q \times B O D_{\text {Influent }} \\
& \quad=134,4^{\mathrm{a}} / \text { hari } \times 40^{9} / \mathrm{m}^{\mathrm{a}} \\
& =5376 \mathrm{~g} \\
& =5,376 \mathrm{~kg} / \text { hari }
\end{aligned}
$$

Beban maksimum untuk BOD5 adalah $75 \mathrm{Kg} / \mathrm{ha}$.hari, dengan luasan CWyang hanya $451,1 \mathrm{~m} 2$ atau 0,0451 kali dari 1 hektar, maka beban maksimum yang diijinkan hanya sebesar $3,38 \mathrm{Kg} / \mathrm{hari}$ sehingga tidak mencukupi untuk menampung beban BOD5. Namun hal ini akan tetap dilanjutkan, dikarenakan di literatur yang lain, yaitu di metcalf \& eddy, beban BOD5 maksimum sebesar $133 \mathrm{Kg} /$ ha.hari, sehingga batas maksium untuk luasan wetland yang direncanakan adalah sebesar 5,9 Kg/ha.hari, dan memenuhi beban maksimum.

Setelah mendapatkan nilai dari BOD5 loading rate, maka dapat ditentukan nilai dari penyisihan SS dari perencanaan $\mathrm{CW}$ yang akan direncanakan. Adapun rumus yang digunakan adalah sebagai berikut.

$$
\begin{aligned}
& \mathrm{Ce}=\mathrm{Co}[0.1058+0.0011(\mathrm{HLR})] \\
& \text { Dimana }: \mathrm{Ce}=\text { efluen TSS, mg/L } \\
& \mathrm{Co}=\text { influen TSS, mg/L } \\
& \text { HLR }=\text { hydraulic-loading rate, cm/hari } \\
& \mathrm{Ce}_{e}=40 \mathrm{mg} / l\left[0,1058+0,0011\left(22,5 \frac{\mathrm{cm}}{\text { hari }}\right)\right] \quad=5,2
\end{aligned}
$$

$\mathrm{mg} / \mathrm{l}$

Efisiensi TSS adalah sebesar $87 \%$

Perhitungan Efisiensi Removal

Setelah ditentukan dimensi CW, maka selanjutnya adalah perhitungan bangunan penampung hujan. Hal ini dikarenakan 
penggunaan lahan khusus untuk CWtelah terpenuhi, maka luas lahan sisa dapat digunakan untuk bangunan penampung hujan, atau biasa disebut bozem. Dalam perhitungan bangunan penampung hukan tidak ada yang khusus, hanya saja ditentukan kedalaman untuk penampung hujan ini adalah 2 meter, setelah ditentukan berapa kedalaman bak penampung hujan, didapat volume total dari bak penampung hujan sebesar $2737 \mathrm{~m} 3$

Setelah mengetahui berapa volume yang dapat ditampung, maka langkah selanjutnya adalah menghitung debit limpasan, dengan rumus sebagai berikut.

$$
\begin{aligned}
& Q=C \times i \times A \\
& \text { Q: Debit (1/detik) } \\
& \text { C: Koefisien Pengaliran } \\
& \text { i: Intensitas Hujan (mm/jam) } \\
& \text { A: Luas Area (ha) }
\end{aligned}
$$

Dengan diketahui intensitas hujan adalah sebesar 78,9433 $\mathrm{mm} / \mathrm{jam}$, luas area perencanaan saluran drainase PUH 2 adalah 53,5 ha, dan nilai $\mathrm{Cr}$ untuk daerah perencanaan sebesar 0,44676, maka debit limpasan adalah

$$
\begin{aligned}
& Q=\frac{0,44676 \times 78,9433^{\text {monk }} / \mathrm{jam} \times 53,5 \mathrm{ha}}{1000} \\
& =1,8 \mathrm{~m} 3 / \text { detik }
\end{aligned}
$$

Setelah mengetahui debit limpasan air hujannya, maka langkah selanjutnya adalah menghitung debit yang dapat ditampung oleh saluran eksisting. Diketahui dimensi saluran eksisting berbentuk persegi adalah $0,7 \mathrm{~m} \times 0,8 \mathrm{~m}$. Untuk mengetahui berapa debitnya, digunakan rumus manning sebagai berikut.

$$
V=\frac{1}{n} R^{\frac{2}{2}} S^{\frac{1}{2}}
$$

Dimana V: Kecepatan (m/s)

R: Jari-jari Hidrolis (A/Keliling Basah)

S: Slope $(0,02)$

$\mathrm{N}$ : Koefisien Manning $(0,018)$

Sehingga dimasukkan dalam perhitungan adalah

$V=\frac{1}{0,018}(0,24)^{\frac{2}{3}} S 0,02^{\frac{1}{2}}$

$$
=3,11 \mathrm{~m} / \mathrm{s}
$$

Dengan Across sebesar 0,56, maka debit dari saluran eksisting adalah

$$
\begin{aligned}
& Q=v_{n} a \\
& Q=3,11^{\mathrm{m} / \mathrm{s}} \times 0,56 \mathrm{~m}^{2} \\
& =1,742 \mathrm{~m} 3 / \text { detik }
\end{aligned}
$$

Dengan $Q$ yang dapat ditampung pada saluran adalah 1,742 $\mathrm{m} 3 /$ detik dan debit limpasan adalah sebesar 1,8m3 sehingga volume yang tidak dapat dapat ditampung adalah 0,058 m3,/detik Nantinya debit yang tidak dapat ditampung oleh saluran eksisting akan dialihkan melalui bozem saat hujan sudah turun.

\section{KESIMPULAN/RINGKASAN}

Kesimpulan dari perencanaan ini adalah sebagai berikut.

A. CWberpengaruh dalam menurunkan beban greywater di perumahan Sutorejo juga dapat menampung hujan yang berlebih sebesar $0,058 \mathrm{~m}^{3} /$ detik

B. CWPerencanaan dapat mengurangi beban BOD sebesar $86,93 \%$, COD $94,28 \%$, dan TSS sebesar $87 \%$

\section{UCAPAN TERIMA KASIH}

Penulis mengucapkan banyak terima kasih pihak pengembang juga pak Supriyadi, satpam di perumahan Sutorejo Tengah V.

\section{DAFTAR PUSTAKA}

[1] Hammer, M.J., 1986, Water and Wastewater Technology SI Version, John Willey \& Sons, Singapore.

[2] Vymazal, J. 2010. Constructed Wetlands for Wastewater Treatment, Journal Water 2010, 2, 530-549, ISSN 20734441.

[3] Lukito A. Marianto, 2004, Merawat dan Menata Tanaman Air, Penerbit Agro Media Pustaka, Jakarta.

[4] Lemke, C., 1999, Plant of the Week; Cyperus alternifolius Umbrella Plant Download internet : www.ou.edu.com. 